\title{
Przemówienie ojca świętego Pawta VI do Międzynarodowej Federacji „Pueri Cantores”, 6 kwietnia 1964
}

Cieszymy się, że możemy powitać uczestników X Międzynarodowego Kongresu „Pueri Cantores”. W sposób szczególny pragniemy powitać wśród obecnych tutaj Mons. Iginego Anglésa, Przewodniczącego Papieskiego Instytutu Muzyki Kościelnej i honorowego Prezydenta Międzynarodowego Stowarzyszenia Muzyki Kościelnej. Jesteśmy mu wdzięczni za jego pracę, pełną kultury i zapału, z jaką poświęca się tym instytucjom, a także sprawie odnowy i rozwoju sztuki muzyki religijnej i kościelnej oraz jej zastosowania w kulcie liturgicznym wedle norm ustanowionych przez Kościół, zgodnych ponadto ze zgłaszanymi potrzebami duchowymi wiernych.

Równie bardzo cieszymy się, że możemy przyjąć tutaj Członków Komitetu „Międzynarodowego Przeglądu Zespołów Muzycznych ku czci Naszej Pani z Loreto", w szczególności myśli nasze biegną ku Dyrygentom paryskiego Instytutu Gregoriańskiego oraz ruchu gregoriańskiego z Francji i innych reprezentowanych tu narodów.

Słowa powitania kierujemy także do Gregorianistów i Gregorianistek z Francji i innych krajów, należących do tego już znakomitego i zasłużonego prądu śpiewu sakralnego, pozwalającego mieć nadzieję, iż tradycyjny śpiew muzyczny łacińskiego Kościoła na nowo zdobędzie podwójną zasługę swej doskonałej interpretacji i jego rozpowszechnionego wykonywania przez liczne zespoły chóralne, a wręcz przez całe zgromadzenia wiernych.

Nasze wyjątkowe pozdrowienie biegnie jednak ku zdolnym „Pueri Cantores” z Anglii, Hiszpanii, Francji, Belgii, Szwajcarii, Niemiec i Włoch, przybyłych do Rzymu na ich Kongres i obecnych tu w Bazylice. Wraz z nimi witamy Prezydenta Międzynarodowej Federacji „Pueri Cantores”, Mons. Fiorenza Romitę, Wiceprezydentów, Prezydentów narodowych, Współpracowników i Współpracownice stałego Sekretariatu tej Federacji w Rzymie i wszystkich Dyrygentów różnych zespołów tutaj przybyłych. Wyrażamy słowa podziwu, wdzięczności i zachęty dla wszystkich, którzy dyrygują, promują i wspierają ten ruch. 
Wiedzcie, że Wasza działalność skupiona na włączeniu dzieci w celebrację liturgiczną poprzez wykonywanie śpiewu sakralnego jest przez nas bardzo doceniana, a to nie tylko ze względu na nutę niewinności, świeżości i piękna, jaką udział „Pueri Cantores” wprowadza do świętych ceremonii z korzyścią dla ludu chrześcijańskiego, ale przez wzgląd na wspaniałą cześć w ten sposób oddawaną Panu, na żywą i miłą pobożność wprowadzaną do publicznego kultu oraz na lepsze przestrzeganie kryteriów i przepisów ogłoszonych w Konstytucji o liturgii świętej przez Ekumeniczny Sobór Watykański II. Ufamy, że wydarzenie to umocni wytrwałość wszystkich pracujących na rzecz ruchu „Pueri Cantores” oraz posłuży jako przykład i bodziec dla wielu innych, ażeby każda katedra, każda parafia, każda katolicka szkoła i każdy inny kościół czy stowarzyszenie, mające taką możliwość i uprawnienia, mogły się szczycić i być przyozdobione czystymi i dźwięcznymi głosami pięknych zastępów „Pueri Cantores”.

A wy, Dzieci, czy słyszycie nas?

Chcemy i do Was coś powiedzieć, bo Wy, „Pueri Cantores”, jesteście przez nas szczególnie umiłowani. Ze względu na Wasz wiek: Jezus bardzo kochał dzieci, a my, którzy reprezentujemy tutaj Jezusa, mówimy Wam i wszystkim Waszym braciom, siostrom i kolegom, że Kościół nadal bardzo Was kocha, a teraz nawet bardziej niż zwykle, ponieważ Kościół wie, że macie w nim wielką zasługę i bardzo go potrzebujecie. Zapewniamy Was o naszej miłości także dlatego, że stoicie wokół ołtarza: nie tylko jako asysta czy pomocnicy, ale jesteście, razem z Kapłanem i innymi celebransami, szafarzami, małymi lecz zdolnymi szafarzami świętych ceremonii. Bardzo lubimy, kiedy jesteście blisko nas podczas nabożeństw, uważni, skupieni, pobożni. Jesteście żywymi kwiatami ołtarza Pańskiego.

A ponadto, śpiewacie. Wasz śpiew, kiedy jest dobrze wykonywany, jest rozkoszą sprawiającą radość tym, którzy Was słuchają. Jesteśmy z tego powodu szczęśliwi.

Być może też Aniołowie cieszą się Waszymi głosami. Chcielibyśmy, aby pieśni Wasze zawsze pozwalały zrozumieć, jak pięknie jest się modlić tak jak Wy, śpiewając z Kościołem i dla Kościoła. Jesteście w Kościele tym, czym w liturgii jest „Alleluja”: ciągle nową radością. Opowiemy Wam nawet pewną historię, jaka wydaje się w sam raz dla Was, o kantorze-męczenniku swojego śpiewu. Mógłby zostać Waszym Patronem, który by Was chronił. Nazwiemy go świętym od Alleluja.

Historia zatem jest taka. To prawdziwa historia, wiecie. Przekazuje ją pewien stary pisarz, biskup z V w., opowiadając o inwazji Wandali w Afryce Północnej. Była ona wówczas regionem, gdzie rozkwitały miasta i cywilizacja, i była chrześcijańska. W jednym z miast Mauretanii, o nazwie Regia, celebrowano (w 427 r.) uroczystości wielkanocne i wierni zgromadzili się w kościele. I nagle, w czasie świętych obrzędów, Wandalowie, barbarzyńcy i w dodatku heretycy, pełni furii rzucili 
się do ataku. Nie mogli jednak wejść, gdyż wierni, w obawie właśnie przed jakimś najazdem, pozamykali wcześniej drzwi kościoła.

Wówczas ci barbarzyńcy wspięli się na dach i dostali się w ten sposób do okna kościoła. W tym momencie, jak mówi historyk, kantor, a my możemy powiedzieć, że jeden z „Pueri Cantores” tamtych czasów, wyśpiewywał słodko z ambony wielkanocne Alleluja. Nagle, jeden z najeźdźców chwycił za łuk i z wysokości okna wypuścił z niego strzałę, która trafiła w samo gardło pobożnego kantora. Wypuścił z rąk nuty, po czym sam upadł i umarł z Alleluja na ustach i z Alleluja na zawsze w duszy (Victor Vitensis, de pers. vand. 1, XIII; PL 58, 197).

Umarł, wyśpiewując chwałę i radość Zmartwychwstałego Jezusa.

Życzymy Wam, drodzy młodzi chórzyści, abyście - przeciwnie - mogli żyć, wyśpiewując Boże Alleluja, lecz z tą samą wiernością i z tą samą pobożnością, na chwałę Pana i ku radości Kościoła.

I tym życzeniem, kochane Dzieci, wszystkim Wam błogosławimy!

Tłumaczenie: Kalina Kreczko 